\title{
Cigarette smoke and lipopolysaccharide induce a proliferative airway smooth muscle phenotype
}

\author{
Tonio Pera*1, Reinoud Gosens ${ }^{1}$, Andries H Lesterhuis', Riham Sami', Marco van der Toorn², Johan Zaagsma and \\ Herman Meurs ${ }^{1}$
}

\begin{abstract}
Background: A major feature of chronic obstructive pulmonary disease (COPD) is airway remodelling, which includes an increased airway smooth muscle (ASM) mass. The mechanisms underlying ASM remodelling in COPD are currently unknown. We hypothesized that cigarette smoke (CS) and/or lipopolysaccharide (LPS), a major constituent of CS, organic dust and gram-negative bacteria, that may be involved in recurrent airway infections and exacerbations in COPD patients, would induce phenotype changes of ASM.

Methods: To this aim, using cultured bovine tracheal smooth muscle (BTSM) cells and tissue, we investigated the direct effects of CS extract (CSE) and LPS on ASM proliferation and contractility.

Results: Both CSE and LPS induced a profound and concentration-dependent increase in DNA synthesis in BTSM cells. CSE and LPS also induced a significant increase in BTSM cell number, which was associated with increased cyclin D1 expression and dependent on activation of ERK 1/2 and P38 MAP kinase. Consistent with a shift to a more proliferative phenotype, prolonged treatment of BTSM strips with CSE or LPS significantly decreased maximal methacholine- and KCl-induced contraction.
\end{abstract}

Conclusions: Direct exposure of ASM to CSE or LPS causes the induction of a proliferative, hypocontractile ASM phenotype, which may be involved in airway remodelling in COPD.

\section{Background}

Chronic obstructive pulmonary disease (COPD) is an inflammatory lung disease characterized by a progressive and largely irreversible airflow obstruction, which involves structural changes of the lung, including emphysema and small airway remodelling [1]. Small airway remodelling in COPD is characterized by adventitial fibrosis and mucus cell hyperplasia, and may involve increased airway smooth muscle (ASM) mass, particularly in severe disease [1-5]. Small airway remodelling may contribute to the reduced lung function as well as to persistent airway hyperresponsiveness, which is present in most of the patients [6,7].

Tobacco smoke exposure is considered to be the most important risk factor for COPD in developed countries. Lipopolysaccharide (LPS) - a constituent of the outer wall of gram-negative bacteria and a contaminant of tobacco

* Correspondence: t.pera@rug.nl

1 Department of Molecular Pharmacology, University Centre for Pharmacy, University of Groningen, Groningen, The Netherlands

Full list of author information is available at the end of the article smoke, organic dust and environmental pollution [8-11] has been implicated in the development and progression of various pulmonary diseases, including COPD [12-14]. Cigarette smoke (CS) and LPS have previously been shown to induce features of airway remodelling in animal models, including airway wall thickening, increased ASM mass, goblet cell hyperplasia and collagen deposition [1519].

Although the mechanisms involved in the development and progression of small airway remodelling in COPD are largely unknown, chronic inflammation of the airways is presumably of major importance. This is indicated by persistent infiltration of inflammatory cells, including macrophages, neutrophils and T- and B-lymphocytes, in the airway wall, which is correlated with the severity of airflow obstruction [3,5].

This inflammatory response is associated with the release of profibrotic cytokines and growth factors, which are linked to a repair and remodelling process that thickens the airway wall and narrows the airway lumen [20]. 
However, small airway remodelling could also result from direct effects of CS and LPS exposure on structural cells of the airway wall, independent of inflammation. Thus, studies using rat tracheal explants [21,22] and a mouse model of CS exposure [23] have shown that CS exposure of the airway wall may lead to the release of TGF- $\beta_{1}$ and upregulation of platelet-derived growth factor (PDGF), connective tissue growth factor (CTGF) and procollagen gene expression independent of inflammatory cell infiltration. The inflammation-independent fibrotic response presumably involves an oxidant-driven mechanism, which may be reinforced by inflammatory cells such as macrophages and neutrophils, known to release oxidants in response to tobacco smoke [24]. In addition, epithelial cells, fibroblasts, as well as ASM cells in culture have been shown to release pro-inflammatory and profibrotic cytokines in response to CS [25-29] or LPS [30-32].

As indicated above, various studies have indicated that increased airway smooth muscle mass may contribute to airway remodelling in COPD [2-5]. Indeed, a direct correlation between the degree of smooth muscle mass and airflow obstruction in COPD has been reported [3,5]. Previous in vitro studies from our laboratory have demonstrated that growth factors, including PDGF, and extracellular matrix (ECM) proteins, including collagen I and fibronectin, induce a proliferative phenotype of bovine tracheal smooth muscle (BTSM), which is accompanied by reduced contractility of the muscle [33-35]. PDGFinduced phenotypic modulation was shown to be mediated by ERK $1 / 2$ and p38 MAP kinase, two signalling molecules that are importantly involved in mitogenic responses of ASM [33,35]. The direct effects of CSE and LPS on ASM proliferation are, however, currently unknown. In this study, we present evidence that both CSE and LPS induce a proliferative, hypocontractile phenotype of ASM independent of inflammation, which could be important in the development and progression of ASM growth in COPD.

\section{Methods}

\section{Isolation of Bovine Tracheal Smooth Muscle Cells}

Bovine tracheae were obtained from local slaughterhouses and transported to the laboratory in KrebsHenseleit buffer of the following composition (mM): $\mathrm{NaCl} 117.5, \mathrm{KCl} 5.60, \mathrm{MgSO}_{4} 1.18, \mathrm{CaCl}_{2} 2.50, \mathrm{NaH}_{2} \mathrm{PO}_{4}$ $1.28, \mathrm{NaHCO}_{3} 25.00$, and glucose 5.50 , pregassed with $5 \%$ $\mathrm{CO}_{2}$ and $95 \% \mathrm{O}_{2} ; \mathrm{pH}$ 7.4. After dissection of the smooth muscle layer and removal of mucosa and connective tissue, tracheal smooth muscle was chopped using a McIlwain tissue chopper, three times at a setting of $500 \mu \mathrm{m}$ and three times at a setting of $100 \mu \mathrm{m}$. Tissue particles were washed two times with Dulbecco's Modified Eagle's
Medium (DMEM), supplemented with $\mathrm{NaHCO}_{3}(7 \mathrm{mM})$, HEPES $(10 \mathrm{mM})$, sodium pyruvate $(1 \mathrm{mM})$, nonessential amino acid mixture (1:100), gentamicin $(45 \mu \mathrm{g} / \mathrm{ml})$, penicillin $(100 \mathrm{U} / \mathrm{ml})$, streptomycin $(100 \mu \mathrm{g} / \mathrm{ml})$, amphotericin B $(1.5 \mu \mathrm{g} / \mathrm{ml})$, and foetal bovine serum (FBS, 0.5\%) (all purchased from GIBCO BRL Life Technologies, Paisley, UK). Enzymatic digestion was performed using the same medium, supplemented with collagenase $\mathrm{P}(0.75 \mathrm{mg} / \mathrm{ml}$, Boehringer, Mannheim, Germany), papain (1 $\mathrm{mg} / \mathrm{ml}$, Boehringer), and Soybean trypsin inhibitor $(1 \mathrm{mg} / \mathrm{ml}$, Sigma Chemical, St. Louis, MO, USA). During digestion, the suspension was incubated in an incubator shaker (Innova 4000 ) at $37^{\circ} \mathrm{C}, 55 \mathrm{rpm}$ for $20 \mathrm{~min}$, followed by a 10 -min period of shaking at $70 \mathrm{rpm}$. After filtration of the obtained suspension over a $50 \mu \mathrm{m}$ gauze, cells were washed three times in supplemented DMEM containing $10 \%$ FBS. This isolation method results in a cell population positive for smooth muscle $\alpha$-actin (95\%) and smooth muscle myosin heavy chain $[33,36]$.

\section{Cigarette Smoke Extract}

Cigarette smoke extract was prepared by combusting 2 research cigarettes (University of Kentucky 2R4F; filters removed), using a peristaltic pump (Watson Marlow 323 E/D, Rotterdam, The Netherlands) and passing the smoke through $25 \mathrm{ml}$ of FBS-free DMEM supplemented with penicillin and streptomycin at a rate of 5 minutes/cigarette. The obtained solution is referred to as $100 \%$ strength.

\section{[3 $\left.{ }^{3}\right]$-Thymidine Incorporation}

BTSM cells were plated in 24-well cluster plates at a density of 50,000 cells per well, and were allowed to attach overnight in $10 \%$ FBS-containing DMEM at $37^{\circ} \mathrm{C}$ in a humidified $5 \% \mathrm{CO}_{2}$ incubator. Cells were washed two times with sterile phosphate-buffered saline (PBS, composition $[\mathrm{mM}] \mathrm{NaCl}, 140.0 ; \mathrm{KCl}, 2.6 ; \mathrm{KH}_{2} \mathrm{PO}_{4}, 1.4$; $\mathrm{Na}_{2} \mathrm{HPO}_{4} .2 \mathrm{H}_{2} \mathrm{O}, 8.1 ; \mathrm{pH} 7.4$ ) and made quiescent by incubation in FBS-free medium, supplemented with apotransferrin (5 $\mu \mathrm{g} / \mathrm{ml}$, human, Sigma), ascorbate $(100 \mu \mathrm{M}$, Merck, Darmstadt, Germany), and insulin ( $1 \mu \mathrm{M}$, bovine pancreas, Sigma) for $72 \mathrm{~h}$. Cells were then washed with PBS and stimulated with LPS (1-10,000 ng/ml), purified from Escherichia coli O55:B5 (Sigma) or PDGF (10 ng/ $\mathrm{ml}$ ) in FBS-free medium for $28 \mathrm{~h}$. Treatment of cells with CSE (1-50\%) lasted $1 \mathrm{~h}$, after which the cells were washed 3 times with PBS and incubated in FBS-free DMEM for another $27 \mathrm{~h}$. $\left[{ }^{3} \mathrm{H}\right]$-thymidine $(0.25 \mu \mathrm{Ci} / \mathrm{ml}$, Amersham, Buckinghamshire, UK) was present during the last $24 \mathrm{~h}$ of the incubations, followed by two washes with PBS at room temperature and one wash with ice-cold 5\% trichloroacetic acid (TCA). Cells were incubated with TCA on ice for $30 \mathrm{~min}$. Subsequently, the acid-insoluble fraction 
was dissolved in $0.5 \mathrm{ml} \mathrm{NaOH}(1 \mathrm{M})$. Incorporated [ $\left.{ }^{3} \mathrm{H}\right]-$ thymidine was quantified by liquid-scintillation counting.

\section{Cell number determination}

BTSM cells were plated in 6-well cluster plates at a density of 100,000 cells/well in medium, containing 10\% FBS. Cells were grown to $50 \%$ confluence after which they were serum-deprived for $72 \mathrm{~h}$. Subsequently, cells were treated with CSE (15\%) 2 times for $1 \mathrm{~h}$, on day 0 and day 2 , respectively, or with LPS $(1 \mu \mathrm{g} / \mathrm{ml})$ or PDGF $(10 \mathrm{ng} / \mathrm{ml})$ for 4 days continuously. On day 4 , the cells were washed twice with PBS and were trypsinized (0.25\% TrypsinEDTA (GIBCO); $15 \mathrm{~min}$ ) and re-suspended in FBS-containing DMEM. Cells were then counted in duplicate, using a hemocytometer. When applied, the MEK inhibitors U0126 (3 $\mu \mathrm{M}$; Tocris Cookson, Bristol, UK) or PD 98059 (30 $\mu \mathrm{M}$, Sigma) and the p38 MAPK inhibitors SB $203580(10 \mu \mathrm{M}$, Tocris) or SB $239063(10 \mu \mathrm{M}$, Sigma $)$ were added to the cells 30 min before stimulation and were present throughout the experiment.

\section{Western blot analysis}

BTSM cells were plated in 6-well cluster plates at a density of 200,000 cells/well in medium, containing $10 \%$ fetal bovine serum. Upon confluence, cells were washed two times with sterile PBS and made quiescent by incubation in serum-free medium, supplemented with apo-transferrin $(5 \mu \mathrm{g} / \mathrm{ml})$ and ascorbate $(100 \mu \mathrm{M})$ for either $24 \mathrm{~h}$, for ERK $1 / 2$ and p38 MAP kinase phopsphorylation, or $72 \mathrm{~h}$, for cyclin D1 expression. Cells were then washed with PBS and stimulated in serum-free medium. To obtain total cell lysates, cells were washed once with ice-cold phosphate-buffered saline (PBS) and then lysed in icecold RIPA buffer (composition: $50 \mathrm{mM}$ Tris, $150 \mathrm{mM}$ $\mathrm{NaCl}, 1 \%$ Igepal CA-630, 1\% deoxycholic acid, $1 \mathrm{mM} \mathrm{NaF}$, $1 \mathrm{mM} \mathrm{Na} \mathrm{VO}_{4}, 10 \mu \mathrm{g} / \mathrm{ml}$ aprotinin, $10 \mu \mathrm{g} / \mathrm{ml}$ leupeptin, 7 $\mu \mathrm{g} / \mathrm{ml}$ pepstatin $\mathrm{A}, 5 \mathrm{mM}$ 2-glycerophosphoric acid, $\mathrm{pH}$ 8.0). Lysates were stored at $-80^{\circ} \mathrm{C}$ until further use. Cultured tissue strip homogenates were prepared by pulverizing the tissue under liquid nitrogen, followed by sonification in ice-cold RIPA buffer. Protein content was determined according to Bradford [37]. Homogenates containing $50 \mu \mathrm{g}$ of protein per lane were then subjected to immunoblot analysis using antibodies against cyclin D1, ERK 1/2, p38 MAP kinase or the phosphorylated

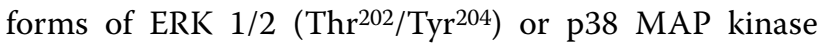
$\left(\mathrm{Thr}^{180} / \mathrm{Tyr}^{182}\right.$ ) (Cell Signaling Technology, Beverly, MA, USA). The antibodies were visualized using enhanced chemiluminescence. Photographs of the blots were scanned and analyzed by densitometry (Totallab ${ }^{\mathrm{mi}}$; Nonlinear Dynamics, Newcastle, UK).

\section{Tissue culture}

After dissection of the smooth muscle layer and careful removal of mucosa and connective tissue, tracheal smooth muscle strips were prepared while incubated in gassed $\mathrm{KH}$-buffer at room temperature. Care was taken to cut tissue strips with macroscopically identical length $(1 \mathrm{~cm})$ and width $(2 \mathrm{~mm})$. Tissue strips were washed once in sterile FBS-free DMEM, supplemented with apo-transferrin $(5 \mu \mathrm{g} / \mathrm{ml})$ and ascorbate $(100 \mu \mathrm{M})$. Next, the tissue strips were transferred into suspension culture flasks containing a volume of $7.5 \mathrm{ml}$ medium. CSE treated strips were exposed to 15\% CSE for $1 \mathrm{~h}$ daily during 8 days. LPS treatment was performed in the continuous presence of 1 $\mu \mathrm{g} / \mathrm{ml}$ LPS during 8 days.

\section{Isometric tension measurements}

Tissue strips, collected from the suspension culture flasks, were washed with several volumes of $\mathrm{KH}$ buffer pregassed with $5 \% \mathrm{CO}_{2}$ and $95 \% \mathrm{O}_{2}, \mathrm{pH} 7.4$ at $37^{\circ} \mathrm{C}$. Subsequently, the strips were mounted for isometric recording (Grass force-displacement transducer FT03) in 20-ml water-jacked organ baths containing $\mathrm{KH}$ buffer at $37^{\circ} \mathrm{C}$, continuously gassed with $5 \% \mathrm{CO}_{2}$ and $95 \% \mathrm{O}_{2}$, $\mathrm{pH}$ 7.4. During a $90-\mathrm{min}$ equilibration period, with washouts every $30 \mathrm{~min}$, resting tension was gradually adjusted to $3 \mathrm{~g}$. Subsequently, the muscle strips were precontracted with 20 and $40 \mathrm{mM}$ isotonic $\mathrm{KCl}$ solutions. Following two washouts, maximal relaxation was established by the addition of $0.1 \mu \mathrm{M}(-)$-isoprenaline (Sigma). In most of the experiments, no basal myogenic tone was detected. Tension was readjusted to $3 \mathrm{~g}$, immediately followed by three washes with fresh $\mathrm{KH}$ buffer. After another equilibration period of $30 \mathrm{~min}$, cumulative concentration response curves were constructed using stepwise increasing concentrations of isotonic $\mathrm{KCl}$ (5.6-50 mM) or methacholine (1 nM-100 $\mu \mathrm{M}$; ICN Biomedicals, Costa Mesa, CA, USA). When maximal tension was obtained, the strips were washed several times, and maximal relaxation was established using $10 \mu \mathrm{M}$ ()-isoprenaline.

\section{Data analysis}

All data represent means \pm s.e. mean from separate experiments. The statistical significance of differences between data was determined by the Student's t-test for paired observations. Differences were considered to be statistically significant when $\mathrm{P}<0.05$.

\section{Results \\ CSE and LPS induce BTSM cell proliferation}

Proliferative responses of isolated BTSM cells to CSE and LPS stimulation were investigated by $\left[{ }^{3} \mathrm{H}\right]$-thymidine incorporation and cell counting. A $1 \mathrm{~h}$ pulse treatment with CSE, followed by $27 \mathrm{~h}$ incubation in serum-free medium resulted in a significant and concentrationdependent increase in $\left[{ }^{3} \mathrm{H}\right]$-thymidine incorporation, reaching a maximum of $187 \pm 13 \%$ of control at a concentration of 15\% (Figure 1A). Similarly, LPS induced a con- 


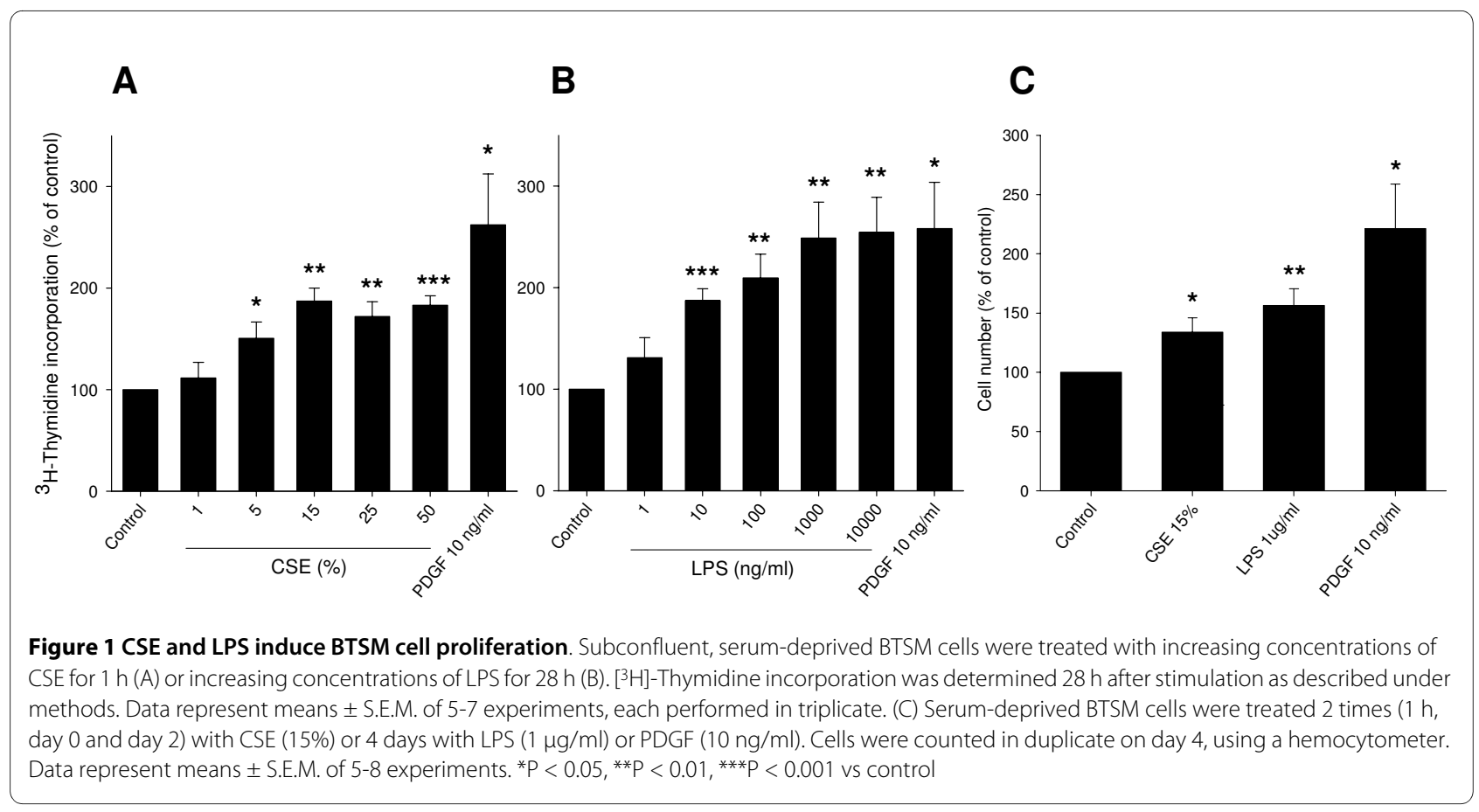

centration-dependent increase in [3 $\mathrm{H}]$-thymidine incorporation of up to $254 \pm 45 \%$ of control, similar to that induced by a submaximal concentration of PDGF (10 ng/ml; $258 \pm 64 \%$ ) (Figure 1B). Treatment of BTSM cells with $15 \%$ CSE (two $1 \mathrm{~h}$ pulses, on day 0 and day 2 ), or 1 $\mu \mathrm{g} / \mathrm{ml}$ LPS resulted in a significant increase in cell number as well, as determined 4 days after starting the treatment (Figure $1 \mathrm{C})$. As a positive control, PDGF $(10 \mathrm{ng} / \mathrm{ml}$, 4 days) similarly increased BTSM cell number (Figure 1C). The combined treatment of cells with CSE (15\%) and LPS $(1 \mu \mathrm{g} / \mathrm{ml})$ had no additional effect on cell numbers when compared to the separate treatments alone (data not shown). Collectively, these data indicate that both CSE and LPS induce proliferation of BTSM cells in a nonadditive fashion.

\section{CSE and LPS induce ERK 1/2 and p38 MAP kinase phosphorylation and cyclin D1 expression}

Western blot analysis was performed to investigate the effects of CSE (15\%) and LPS $(1 \mu \mathrm{g} / \mathrm{ml})$ on phosphorylation of ERK $1 / 2$ and p38 MAP kinase, two major signalling pathways involved in ASM cell proliferation, and on the expression of cyclin D1, a key regulator of cell cycle progression downstream of ERK $1 / 2$ and p38 MAP kinase. Both CSE and LPS induced a rapid phosphorylation of ERK 1/2 (Figure 2). Both stimuli also induced a rapid phosphorylation of p38 MAP kinase, which, similarly to ERK $1 / 2$ phosphorylation, was sustained (Figure 3). In addition, both CSE and LPS significantly increased the expression of cyclin D1, as assessed after $24 \mathrm{~h}$, to a similar extent as $30 \mathrm{ng} / \mathrm{ml}$ PDGF (Figure 4), suggesting an important role for these signalling pathways in the proliferative response induced by CSE and LPS.

\section{Role of ERK 1/2 and p38 MAP kinase in CSE- and LPS- induced proliferation}

To test this hypothesis, the effect of CSE or LPS on cell number was determined in the presence or absence of U0126 $(3 \mu \mathrm{M})$, an inhibitor of MEK, the upstream activator of ERK 1/2, or SB $203580(10 \mu \mathrm{M})$, an inhibitor of p38 MAP kinase. As illustrated in Figures 5A and 5B, inhibition of MEK by U0126 and inhibition of p38 MAP kinase by SB 203580 completely abrogated the CSE- and LPSinduced increase in cell number. By contrast, no effect of the kinase inhibitors on basal cell numbers was observed. These findings were confirmed by using PD 98059 (30 $\mu \mathrm{M})$ and SB $239063(10 \mu \mathrm{M})$, alternative inhibitors for MEK and p38 MAP kinase, respectively (Figures 5C and 5D). Together with the CSE- and LPS-induced phosphorylation of ERK $1 / 2$ and p38 MAP kinase described above, these data indicate that CSE- and LPS-induced proliferation is dependent on activation of the ERK $1 / 2$ and p38 MAP kinase signalling pathways.

\section{Effects of LPS and CSE on BTSM contractility}

Previous studies have shown that the proliferative response of BTSM cells to growth factors and ECM proteins is linearly related to a decrease in contractility of BTSM tissue [33,34]. In order to investigate the effects of CSE and LPS on BTSM phenotype, strips were cultured for 8 days with $1 \mu \mathrm{g} / \mathrm{ml}$ LPS or were subjected to daily exposure to $15 \%$ CSE for $1 \mathrm{~h}$ during 8 days. After both 


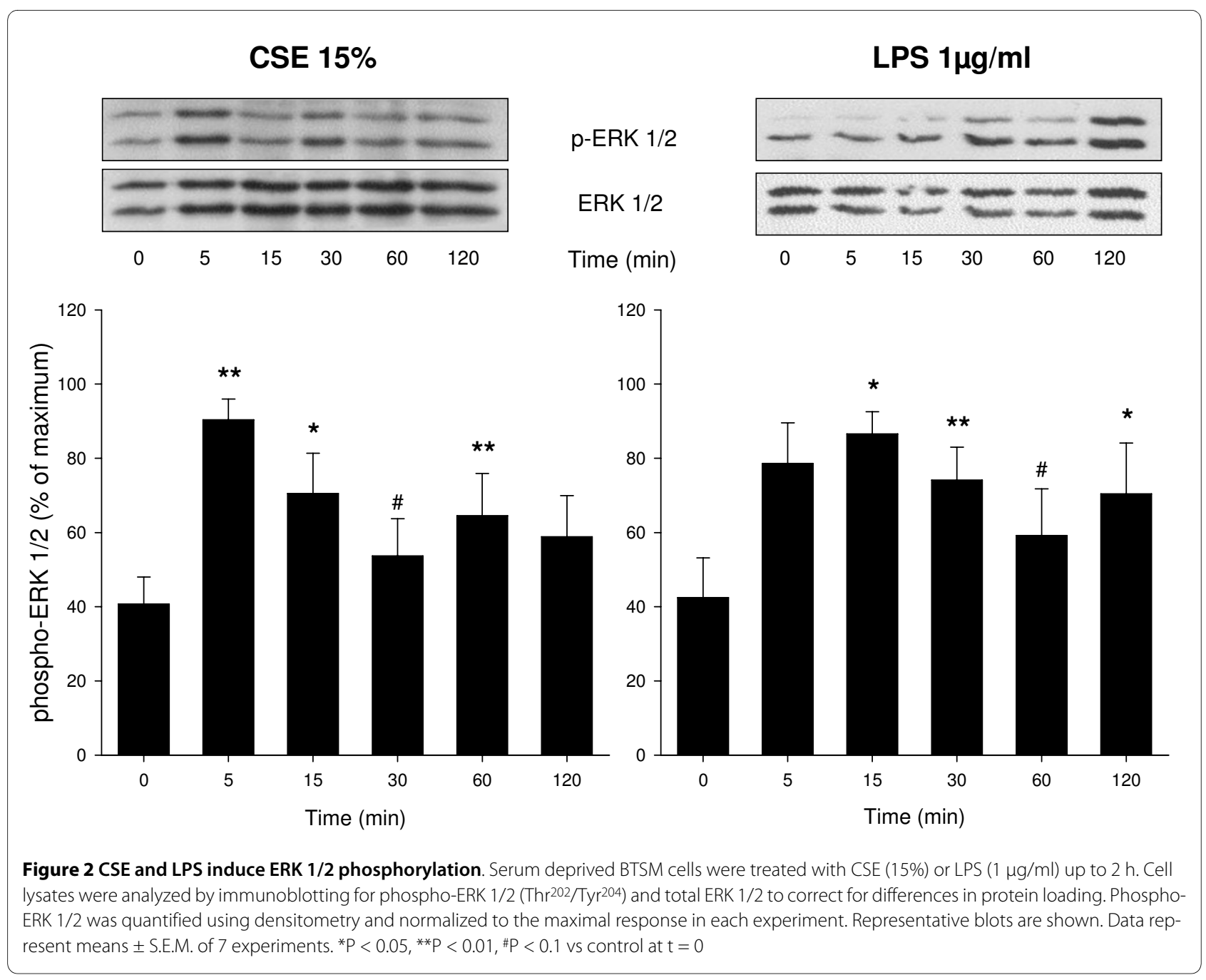

treatments, maximal contraction induced by methacholine or $\mathrm{KCl}$ was significantly reduced compared to untreated strips (Figures 6A and 6B). No differences in the sensitivity $\left(-\log \mathrm{EC}_{50}\right)$ to methacholine and $\mathrm{KCl}$ were found. These effects were associated with increased ERK $1 / 2$ and p38 MAP kinase phosphorylation in the tissue (Figure 7). Collectively, these results indicate that both CSE and LPS induce a shift to a hypocontractile and proliferative ASM phenotype.

\section{Discussion}

In this study, we demonstrated for the first time that CSE and LPS induce a profound and concentration-dependent increase in DNA synthesis and cell number of cultured ASM cells. The CSE- and LPS-induced proliferation is dependent on phosphorylation of ERK $1 / 2$ and p38 MAP kinase and downstream mitogenic signalling. In addition, we demonstrated that CSE and LPS treatments reduce the maximal contraction of ASM preparations to methacholine and $\mathrm{KCl}$, which is also associated with increased
ERK $1 / 2$ and p38 MAP kinase phosphorylation. Collectively, these data indicate that CSE and LPS induce a phenotype shift of ASM to a proliferative and less contractile phenotype that could be involved in airway remodelling in COPD.

Although small airway remodelling has been associated with cellular inflammation, evidence suggesting that direct action of cigarette smoke on the airway wall is involved in airway remodelling is accumulating. In rat tracheal explants, Wang and colleagues [21,22] demonstrated direct effects of CS on the release of active TGF$\beta_{1}$, with subsequent phosphorylation of Smad-2 and upregulation of CTGF and procollagen gene expression. In addition, in a cell-free system, cigarette smoke extract was found to release active TGF- $\beta_{1}$ from (recombinant) latent TGF- $\beta_{1}$ via an oxidative mechanism [22]. Acute CS exposure of mice may also induce a transient increase in TGF- $\beta_{1^{-}}$, CTGF-, procollagen- and PDGF-gene expression and Smad-2 phosphorylation [23]. While the maximal response was observed $2 \mathrm{~h}$ after CS exposure, the 


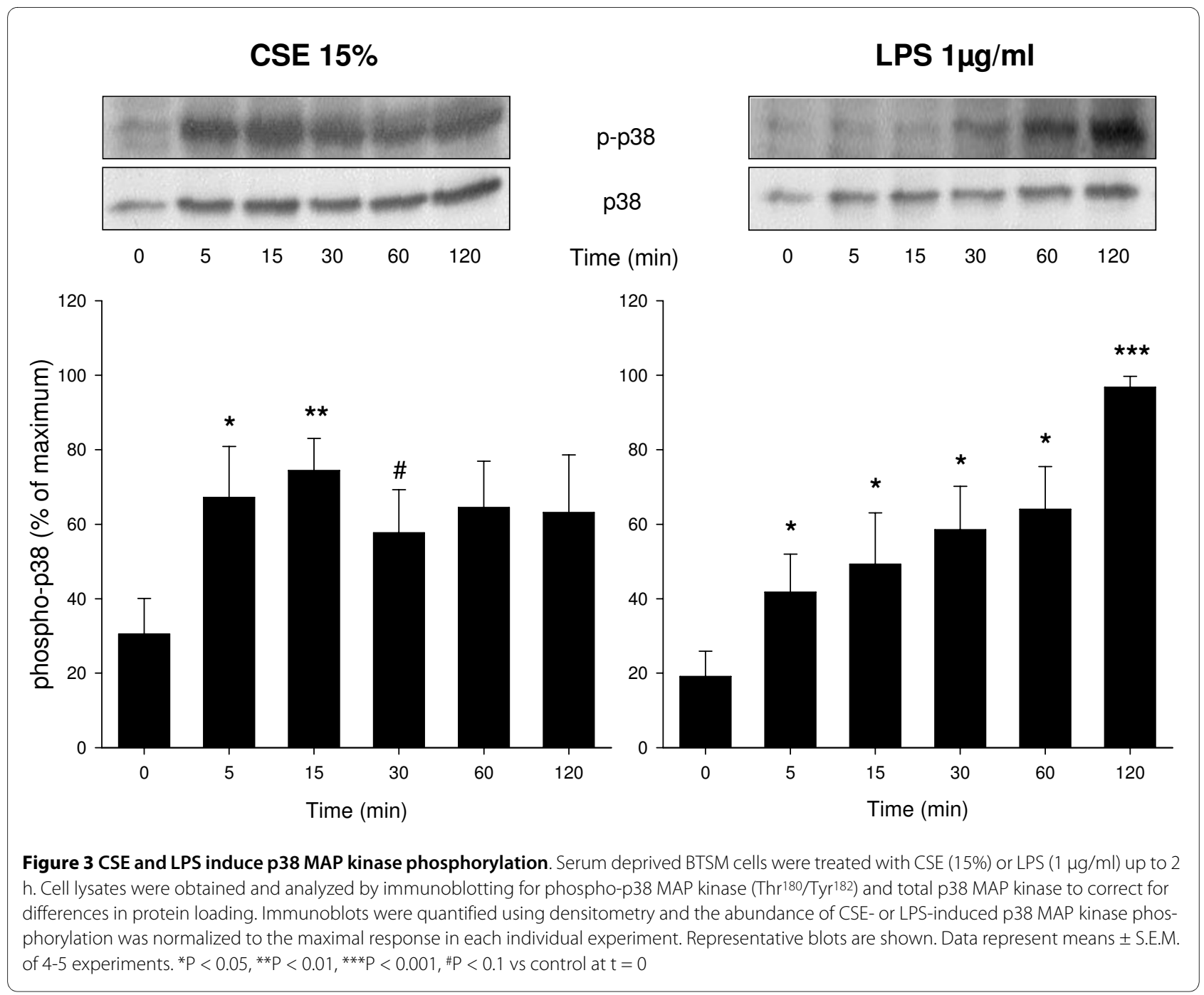

increase in inflammatory cell numbers was only significant after $24 \mathrm{~h}$, by which time the gene expression had subsided. This indicates that a dissociation between profibrotic remodelling responses and inflammatory cell responses may occur. Chronic CS exposure of these mice resulted in a persistent increase in gene expression of above-mentioned factors and an increase in airway wall collagen. Collectively, these data indicate that CS may initiate airway remodelling by inducing profibrotic growth factors in the airway wall, which can lead to increased deposition of matrix proteins. In addition, these observations imply that CS creates conditions which are strongly mitogenic to ASM, since both growth factors and collagen promote ASM proliferation, which may lead to an increase in ASM mass $[33,34,38]$. Our present observations indicate that a direct effect of CS on ASM proliferation may also be involved in airway remodelling. To what extent autocrine processes, involving the release of growth factors and/or pro-proliferative ECM proteins by these cells $[39,40]$, may play a role, is currently unknown.
Remarkably, previous reports [41] have indicated that CSE may also augment proliferation of passively sensitized human ASM cells.

Prolonged exposure of cultured airway structural cells, including ASM cells, to CSE may have cytotoxic effects on these cells by inducing apoptosis and necrosis in a concentration- and time-dependent manner [42-45]. Thus, in human ASM cells, a time- and concentrationdependent induction of cell-cycle arrest, apoptosis and necrosis by exposure to $2,5-20 \%$ CSE for $24-72 \mathrm{~h}$ has been demonstrated [42]. Accordingly, the viability of our BTSM cells was reduced after $24 \mathrm{~h}$ continuous incubation of the cells with 15\% CSE (not shown). However, it was found that short, pulsed exposures of ASM cells to 5 $50 \%$ CSE have a proliferative rather than a toxic effect on these cells. This is of major importance, as this approach seems to be a more suitable model for mimicking the in vivo effects of CS than continuous exposure to high concentrations of CSE for several hours. In addition, CSE exposure may be a more suitable approach for studying 


\section{Cyclin D1}

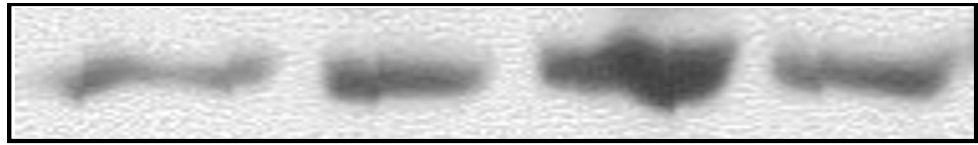

B-actin

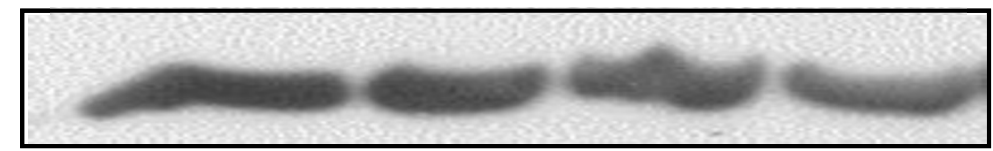

Control

LPS

PDGF

CSE

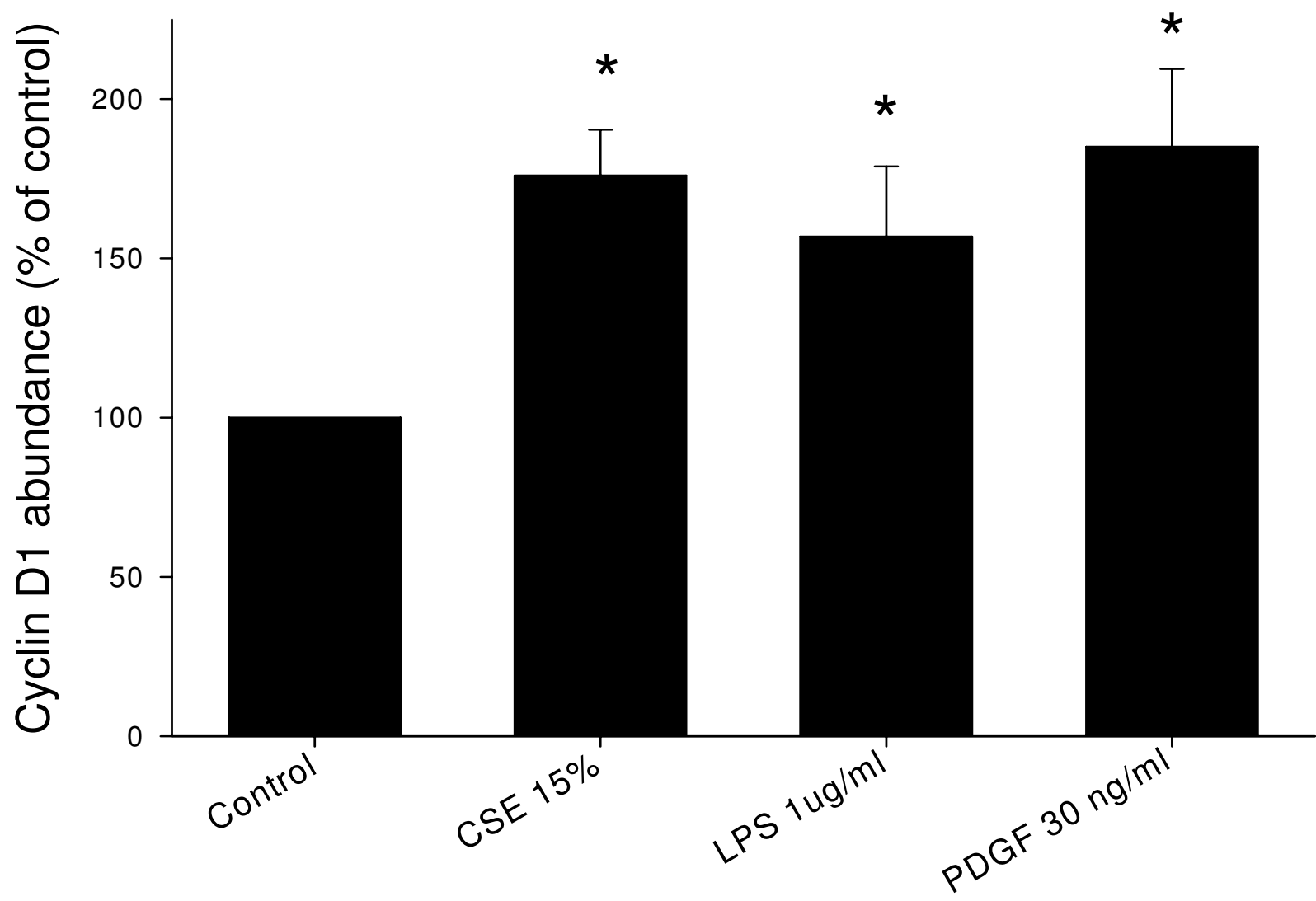

Figure 4 CSE and LPS increase cyclin D1 expression. Serum-deprived BTSM cells were treated with CSE (15\%) for $1 \mathrm{~h}$, or LPS (1 $\mu \mathrm{g} / \mathrm{ml})$ or PDGF (30 $\mathrm{ng} / \mathrm{ml}$ ) for $24 \mathrm{~h}$. Cell lysates were obtained $24 \mathrm{~h}$ after stimulation and analyzed by immunoblotting for cyclin D1 and $\beta$-actin to correct for protein loading. Cyclin D1 was quantified using densitometry and normalized to control expression. Data represent means \pm S.E.M. of 4-7 experiments. ${ }^{*} \mathrm{P}<$ 0.05 vs control

the direct, epithelium-independent effects of CS on ASM, as during smoking ASM is not directly exposed to CS but indirectly, to components of CS after passing the epithelial barrier.

LPS activates the Toll-like receptor 4 (TLR4) signalling pathway, causing activation NF- $\mathrm{B}$ and $\mathrm{AP} 1$, which results in transcription of pro-inflammatory cytokine genes and initiation of the innate immune response [46]. In human subjects, acute experimental LPS inhalation leads to pulmonary and systemic inflammatory responses associated with airways obstruction and increased airway responsiveness $[47,48]$. Chronic exposure to LPS-containing dust or bio-aerosol in occupational or home environment has also been associated with persistent airway inflammation, decline of lung function and airway hyperresponsiveness [14,49,50]. Moreover, LPS exposure may contribute to the severity of asthma [50]. LPS may be importantly involved in bacterial infection-induced exacerbations of COPD, which contribute to the progression of the disease and diminish the quality of life [51-53]. In 


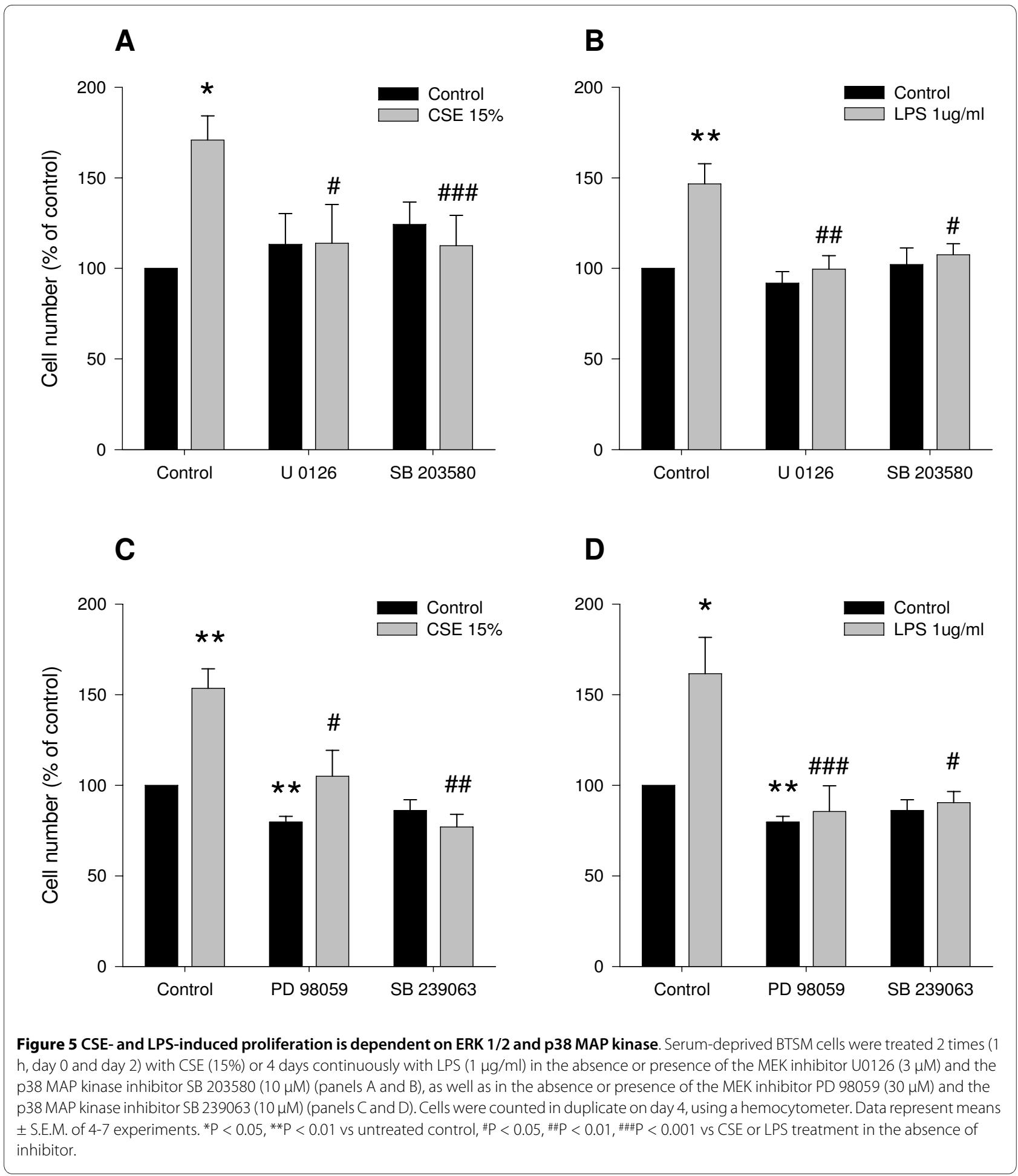

animal models, exposure to LPS induces various inflammatory and pathological changes closely mimicking COPD, including airway remodelling and emphysema $[17,18,54]$. Our present data provide evidence that a direct effect of LPS on ASM cell proliferation may contribute to airway remodelling. Although it has been reported that tobacco smoke is contaminated with LPS [8], LPS is unlikely to have contributed to the CSEinduced effects presented in this study, since LPS concentrations in the CSE were hardly detectable and far below the concentrations needed to induce ASM cell proliferation (not shown). This is in accordance with previous 

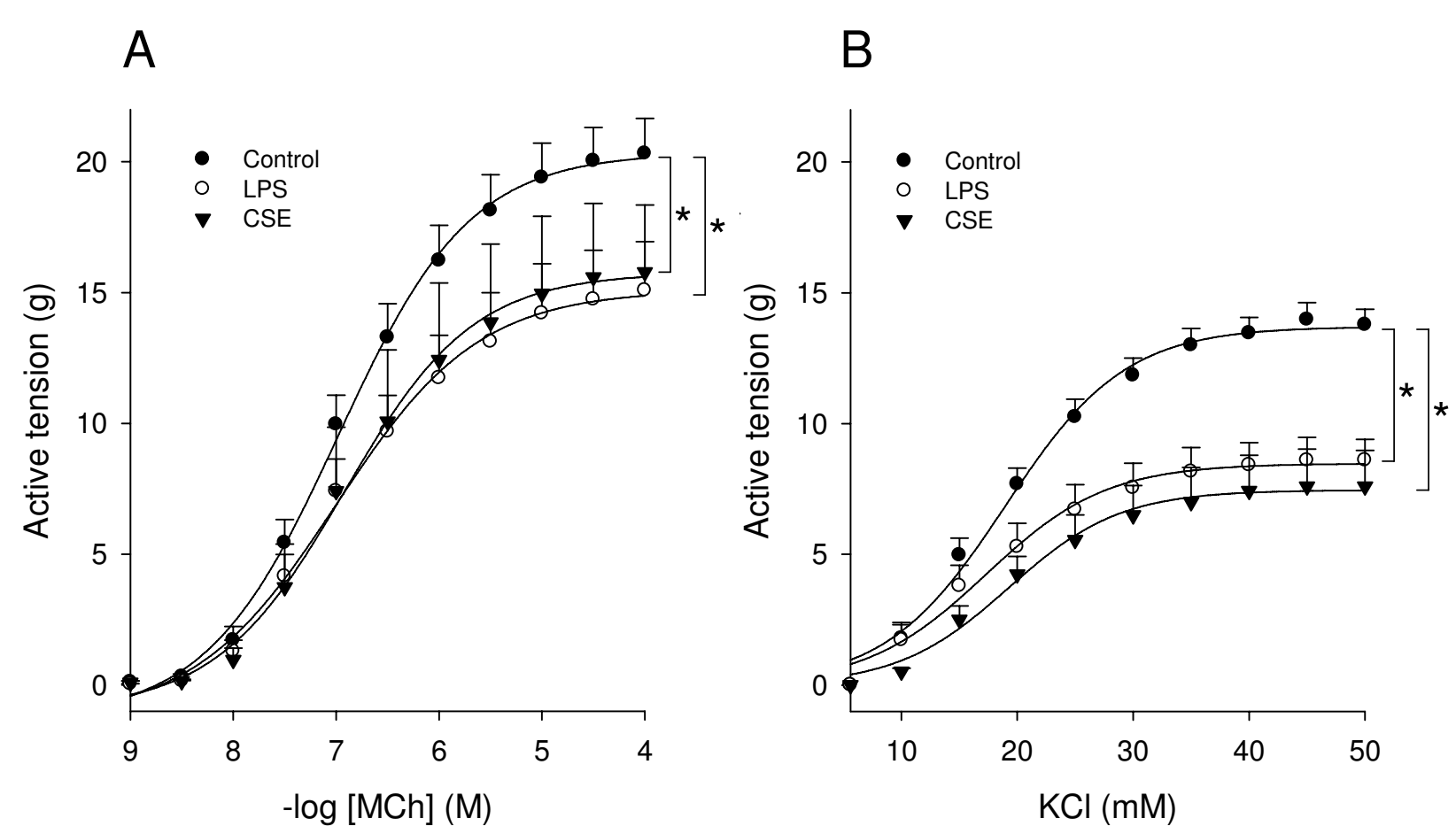

Figure 6 CSE and LPS induce BTSM hypocontractility. Methacholine (A)- and KCI (B)-induced contractions of BTSM strips cultured for 8 days with or without LPS $(1 \mu \mathrm{g} / \mathrm{ml})$ or exposed to 15\% CSE for $1 \mathrm{~h}$ daily during 8 days. Data represent means \pm S.E.M. of 4-6 experiments, each performed in duplicate. ${ }^{* P}<0.05$ vs control.

studies demonstrating that the LPS concentration in CSE is very low and that neutralisation of LPS in CSE, using polymyxin $B$, does not affect the CSE-induced IL-8 release by human macrophages [55]. In addition, we investigated the effect of combined CSE and LPS treatment on ASM cell proliferation, since both factors may be involved simultaneously in exacerbations of COPD. However, no additive effects were observed, clearly indicating that both stimuli act via common pathways, as previously also suggested by others [55].

ASM cells display phenotypic plasticity, characterized by reversible changes in contractile, proliferative and synthetic characteristics, and governed by a variety of growth factors, cytokines, G-protein-coupled receptor agonists and ECM proteins [33-35,38,56-59]. In vitro, smooth muscle-specific contractile protein expression is reduced in response to serum-rich media or growth factors, leading to a decrease in contractility, whereas the proliferative capacity is increased $[33,35,57,58]$. Previous studies have shown that ERK $1 / 2$ and p38 MAP kinase are importantly involved in PDGF-induced proliferation and hypocontractility of ASM [33,35]. Indeed, activation of ERK $1 / 2$ has been shown to increase the expression of cyclin D1, a key regulator of $G_{1}$ phase cell cycle progression $[60,61]$ and to play a fundamental role in ASM cell proliferation [60,62-64]. p38 MAP kinase activation has also been shown to contribute to ASM cell cycle progression and proliferation [33,35,65-68], although this may depend on the mitogen used $[65,68]$. The present study demonstrated that both CSE and LPS induce phosphorylation of ERK $1 / 2$ and p38 MAP kinase as well as increased expression of cyclin D1 in BTSM cells, whereas inhibition of ERK $1 / 2$ and p38 MAP kinase prevented the CSE- and LPS-induced proliferation of these cells. As a possible mechanism that may be involved, CSE was recently shown to induce ERK $1 / 2$ and p38 MAP kinase phosphorylation through NADPH oxidase-induced reactive oxygen species (ROS) formation in human ASM cells [69]. NADPH oxidase has previously also been shown to be involved in proliferative effects of TGF- $\beta_{1}$ in these cells [70].

Expression of TLR4 receptors [31,32] and LPS-induced ERK $1 / 2$ and p38 MAP kinase phosphorylation $[31,71]$ in ASM cells have previously been reported as well. Remarkably, in rabbit ASM, it was shown that LPSinduced ERK 1/2 and p38 MAP kinase activation had opposing effects on LPS-induced hypercontractility [31]. The LPS-induced hypercontractility of rabbit ASM preparations seems to be at variance with our observation of an LPS-induced hypocontractility of BTSM. Difference in duration of LPS treatment ( $24 \mathrm{~h}$ vs 8 days in our study) as well as species differences could possibly underlie this 


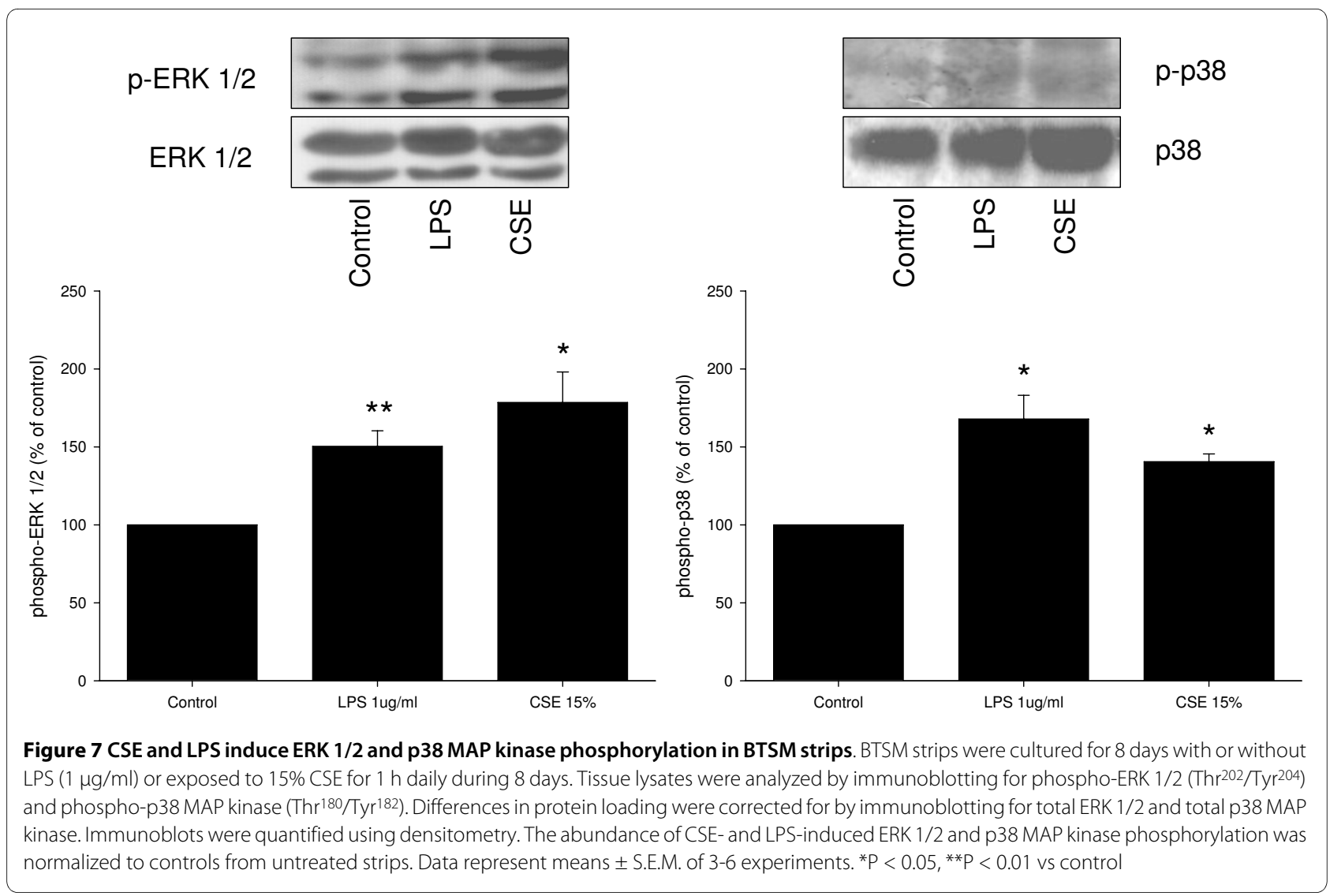

difference. Indeed, a previous study from our lab indicated that at least 4 days of treatment with FBS was required to induce a proliferative BTSM phenotype with a significant decrease in contractility [33]. A hypocontractile ASM phenotype has also been observed after long-term incubation of ASM preparations with other growth factors, including PDGF and IGF-1 [33] as well as with pro-proliferative ECM proteins, such as collagen I and fibronectin [34]. It has been demonstrated that the reduced contractility induced by growth factors and ECM proteins is accompanied by reduced expression of contractile proteins, such as sm-myosin, calponin and sm- $\alpha$ actin [34]. Such a mechanism could also underlie CSEand LPS-induced hypocontractility of BTSM. Thus, CSE as well as LPS reduced the maximal contractile response to both a receptor-dependent (methacholine) and a receptor-independent $(\mathrm{KCl})$ stimulus, indicating that post-receptor alterations such as reduced contractile protein expression are likely to be involved.

\section{Conclusions}

In conclusion, our in vitro data provide evidence that both CSE and LPS may contribute to airway remodelling in COPD through direct effects on ASM cells causing a proliferative phenotype that may be involved in increased ASM mass in this disease.

\section{Competing interests}

The authors declare that they have no competing interests.

\section{Authors' contributions}

TP carried out the proliferation and the contractility studies, performed the statistical analysis, participated in conceiving and designing the study and drafted the manuscript. RG participated in designing the study and revised the manuscript. AHL performed western analysis and participated in the proliferation studies. RS performed western analysis. MvdT participated in designing the study. JZ participated in conceiving and designing the study and revising the manuscript. HM conceived the study, participated in designing the study and revised the manuscript. All authors have read and approved the final manuscript.

\section{Acknowledgements}

The authors would like to thank L.E.M. Kistemaker and M. van der Vegt for technical assistance. This study was financially supported by Boehringer Ingelheim Pharma GmbH \& Co. KG and the Graduate School of Behavioral and Cognitive Neurosciences, University of Groningen, Groningen, The Netherlands.

\section{Author Details}

1Department of Molecular Pharmacology, University Centre for Pharmacy, University of Groningen, Groningen, The Netherlands and 2Laboratory of Allergology and Pulmonary Diseases, University Medical Center Groningen, Groningen, The Netherlands

Received: 23 July 2009 Accepted: 29 April 2010

Published: 29 April 2010 


\section{References}

1. Hogg JC, Timens W: The pathology of chronic obstructive pulmonary disease. Annu Rev Pathol 2009, 4:435-459.

2. Bosken $\mathrm{CH}$, Wiggs BR, Pare PD, Hogg JC: Small airway dimensions in smokers with obstruction to airflow. Am Rev Respir Dis 1990 142:563-570.

3. Saetta M, Di SA, Turato G, Facchini FM, Corbino L, Mapp CE, Maestrelli P, Ciaccia A, Fabbri LM: CD8+ T-lymphocytes in peripheral airways of smokers with chronic obstructive pulmonary disease. Am J Respir Crit Care Med 1998, 157:822-826.

4. Kuwano K, Bosken CH, Pare PD, Bai TR, Wiggs BR, Hogg JC: Small airways dimensions in asthma and in chronic obstructive pulmonary disease. Am Rev Respir Dis 1993, 148:1220-1225.

5. Hogg JC, Chu F, Utokaparch S, Woods R, Elliott WM, Buzatu L, Cherniack RM, Rogers RM, Sciurba FC, Coxson HO, Pare PD: The nature of smallairway obstruction in chronic obstructive pulmonary disease. NEng/J Med 2004, 350:2645-2653.

6. Tashkin DP, Altose MD, Bleecker ER, Connett JE, Kanner RE, Lee WW, Wise $R$ : The lung health study: airway responsiveness to inhaled methacholine in smokers with mild to moderate airflow limitation. The Lung Health Study Research Group. Am Rev Respir Dis 1992, 145:301-310.

7. Postma DS, Kerstjens HA: Characteristics of airway hyperresponsiveness in asthma and chronic obstructive pulmonary disease. Am J Respir Crit Care Med 1998, 158:S187-S192.

8. Hasday JD, Bascom R, Costa JJ, Fitzgerald T, Dubin W: Bacterial endotoxin is an active component of cigarette smoke. Chest 1999, 115:829-835.

9. Rylander R: Endotoxin in the environment--exposure and effects. J Endotoxin Res 2002, 8:241-252.

10. Larsson L, Szponar B, Pehrson C: Tobacco smoking increases dramatically air concentrations of endotoxin. Indoor Air 2004, 14:421-424

11. Larsson L, Szponar B, Ridha B, Pehrson C, Dutkiewicz J, Krysinska-Traczyk E, Sitkowska J: Identification of bacterial and fungal components in tobacco and tobacco smoke. Tob Induc Dis 2008, 4:4

12. Sarir $H$, Henricks PA, van Houwelingen AH, Nijkamp FP, Folkerts G: Cells, mediators and Toll-like receptors in COPD. Eur J Pharmacol 2008, 585:346-353.

13. George CL, Jin H, Wohlford-Lenane CL, O'Neill ME, Phipps JC, O'Shaughnessy P, Kline JN, Thorne PS, Schwartz DA: Endotoxin responsiveness and subchronic grain dust-induced airway disease. Am J Physiol Lung Cell Mol Physiol 2001, 280:L203-L213.

14. Vogelzang PF, Gulden JW van der, Folgering H, Kolk JJ, Heederik D, Preller $\mathrm{L}$, Tielen MJ, van Schayck CP: Endotoxin exposure as a major determinant of lung function decline in pig farmers. Am J Respir Crit Care Med 1998, 157:15-18

15. Wright JL, Postma DS, Kerstjens HA, Timens W, Whittaker P, Churg A: Airway remodeling in the smoke exposed guinea pig model. Inhal Toxicol 2007, 19:915-923.

16. Churg A, Wang R, Wang X, Onnervik PO, Thim K, Wright JL: Effect of an MMP-9/MMP-12 inhibitor on smoke-induced emphysema and airway remodelling in guinea pigs. Thorax 2007, 62:706-713.

17. Toward TJ, Broadley KJ: Goblet cell hyperplasia, airway function, and leukocyte infiltration after chronic lipopolysaccharide exposure in conscious Guinea pigs: effects of rolipram and dexamethasone. J Pharmacol Exp Ther 2002, 302:814-821.

18. Vernooy JH, Dentener MA, van Suylen RJ, Buurman WA, Wouters EF: Longterm intratracheal lipopolysaccharide exposure in mice results in chronic lung inflammation and persistent pathology. Am J Respir Cell Mol Biol 2002, 26:152-159.

19. Brass DM, Savov JD, Gavett SH, Haykal-Coates N, Schwartz DA: Subchronic endotoxin inhalation causes persistent airway disease. Am J Physiol Lung Cell Mol Physiol 2003, 285:L755-L761.

20. Jeffery PK: Remodeling in asthma and chronic obstructive lung disease. Am J Respir Crit Care Med 2001, 164:S28-S38

21. Wang RD, Tai H, Xie C, Wang X, Wright JL, Churg A: Cigarette smoke produces airway wall remodeling in rat tracheal explants. Am J Respir Crit Care Med 2003, 168:1232-1236.

22. Wang RD, Wright JL, Churg A: Transforming growth factor-beta1 drives airway remodeling in cigarette smoke-exposed tracheal explants. Am J Respir Cell Mol Biol 2005, 33:387-393.
23. Churg A, Tai H, Coulthard T, Wang R, Wright JL: Cigarette smoke drives small airway remodeling by induction of growth factors in the airway wall. Am J Respir Crit Care Med 2006, 174:1327-1334.

24. Churg A, Cosio M, Wright JL: Mechanisms of cigarette smoke-induced COPD: insights from animal models. Am J Physiol Lung Cell Mol Physiol 2008, 294:L612-L631.

25. Mio T, Romberger DJ, Thompson AB, Robbins RA, Heires A, Rennard SI: Cigarette smoke induces interleukin-8 release from human bronchial epithelial cells. Am J Respir Crit Care Med 1997, 155:1770-1776.

26. Numanami H, Koyama S, Nelson DK, Hoyt JC, Freels JL, Habib MP, Amano J, Haniuda M, Sato E, Robbins RA: Serine protease inhibitors modulate smoke-induced chemokine release from human lung fibroblasts. Am J Respir Cell Mol Biol 2003, 29:613-619.

27. Oltmanns U, Chung KF, Walters M, John M, Mitchell JA: Cigarette smoke induces IL-8, but inhibits eotaxin and RANTES release from airway smooth muscle. Respir Res 2005, 6:74.

28. Oltmanns U, Walters M, Sukkar M, Xie S, Issa R, Mitchell J, Johnson M, Chung KF: Fluticasone, but not salmeterol, reduces cigarette smokeinduced production of interleukin-8 in human airway smooth muscle. Pulm Pharmacol Ther 2008, 21:292-297.

29. Pace E, Ferraro M, Siena L, Melis M, Montalbano AM, Johnson M, Bonsignore MR, Bonsignore G, Gjomarkaj M: Cigarette smoke increases Toll-like receptor 4 and modifies lipopolysaccharide-mediated responses in airway epithelial cells. Immunology 2008, 124:401-411.

30. Koyama S, Sato E, Nomura H, Kubo K, Miura M, Yamashita T, Nagai S, Izumi $\mathrm{T}$ : The potential of various lipopolysaccharides to release IL-8 and GCSF. Am J Physiol Lung Cell Mol Physiol 2000, 278:L658-L666.

31. Shan X, Hu A, Veler H, Fatma S, Grunstein JS, Chuang S, Grunstein MM: Regulation of Toll-like receptor 4-induced proasthmatic changes in airway smooth muscle function by opposing actions of ERK $1 / 2$ and p38 MAPK signaling. Am J Physiol Lung Cell Mol Physiol 2006, 291:L324-L333.

32. Sukkar MB, Xie S, Khorasani NM, Kon OM, Stanbridge R, Issa R, Chung KF: Toll-like receptor 2, 3, and 4 expression and function in human airway smooth muscle. J Allergy Clin Immunol 2006, 118:641-648.

33. Gosens R, Meurs H, Bromhaar MM, McKay S, Nelemans SA, Zaagsma J: Functional characterization of serum- and growth factor-induced phenotypic changes in intact bovine tracheal smooth muscle. $\mathrm{Br} J$ Pharmacol 2002, 137:459-466.

34. Dekkers BG, Schaafsma D, Nelemans SA, Zaagsma J, Meurs H: Extracellular matrix proteins differentially regulate airway smooth muscle phenotype and function. Am J Physiol Lung Cell Mol Physiol 2007, 292:L1405-L1413.

35. Gosens R, Schaafsma D, Meurs H, Zaagsma J, Nelemans SA: Role of Rhokinase in maintaining airway smooth muscle contractile phenotype. Eur J Pharmacol 2004, 483:71-78.

36. Schaafsma D, McNeill KD, Stelmack GL, Gosens R, Baarsma HA, Dekkers BG, Frohwerk E, Penninks JM, Sharma P, Ens KM, Nelemans SA, Zaagsma J, Halayko AJ, Meurs $\mathrm{H}$ : Insulin increases the expression of contractile phenotypic markers in airway smooth muscle. Am J Physiol Cell Physiol 2007, 293:C429-C439.

37. Bradford MM: A rapid and sensitive method for the quantitation of microgram quantities of protein utilizing the principle of protein-dye binding. Anal Biochem 1976, 72:248-254

38. Hirst SJ, Twort CH, Lee TH: Differential effects of extracellular matrix proteins on human airway smooth muscle cell proliferation and phenotype. Am J Respir Cell Mol Biol 2000, 23:335-344

39. Coutts A, Chen G, Stephens N, Hirst S, Douglas D, Eichholtz T, Khalii N Release of biologically active TGF-beta from airway smooth muscle cells induces autocrine synthesis of collagen. Am J Physiol Lung Cell Mol Physiol 2001, 280:L999-1008

40. Panettieri RA, Tan EM, Ciocca V, Luttmann MA, Leonard TB, Hay DW: Effects of LTD4 on human airway smooth muscle cell proliferation, matrix expression, and contraction In vitro: differential sensitivity to cysteinyl leukotriene receptor antagonists. Am J Respir Cell Mol Biol 1998, 19:453-461

41. Lin J, Xu Y, Zhang Z, Ni W, Chen S: Effect of cigarette smoke extract on the role of protein kinase $C$ in the proliferation of passively sensitized human airway smooth muscle cells. J Huazhong Univ Sci Technolog Med Sci 2005, 25:269-273.

42. Hu W, Xie J, Zhao J, Xu Y, Yang S, Ni W: Involvement of Bcl-2 Family in Apoptosis and Signal Pathways Induced by Cigarette Smoke Extract in 
the Human Airway Smooth Muscle Cells. DNA Cell Biol 2008 , 28(1):13-22.

43. Ishii T, Matsuse T, Igarashi H, Masuda M, Teramoto S, Ouchi Y: Tobacco smoke reduces viability in human lung fibroblasts: protective effect of glutathione S-transferase P1. Am J Physiol Lung Cell Mol Physiol 2001, 280:L1189-L1195.

44. Slebos DJ, Ryter SW, van der TM, Liu F, Guo F, Baty CJ, Karlsson JM, Watkins SC, Kim HP, Wang X, Lee JS, Postma DS, Kauffman HF, Choi AM: Mitochondrial localization and function of heme oxygenase- 1 in cigarette smoke-induced cell death. Am J Respir Cell Mol Biol 2007, 36:409-417.

45. van der TM, Slebos DJ, de Bruin HG, Leuvenink HG, Bakker SJ, Gans RO, Koeter GH, van Oosterhout AJ, Kauffman HF: Cigarette smoke-induced blockade of the mitochondrial respiratory chain switches lung epithelial cell apoptosis into necrosis. Am J Physiol Lung Cell Mol Physiol 2007, 292:L1211-L1218.

46. Akira S, Takeda K, Kaisho T: Toll-like receptors: critical proteins linking innate and acquired immunity. Nat Immunol 2001, 2:675-680.

47. Michel O, Nagy AM, Schroeven M, Duchateau J, Neve J, Fondu P, Sergysels R: Dose-response relationship to inhaled endotoxin in normal subjects. Am J Respir Crit Care Med 1997, 156:1157-1164.

48. Zwan JC Van der, Orie NG, Kauffman HF, Wiers PW, de VK: Bronchial obstructive reactions after inhalation with endotoxin and precipitinogens of Haemophilus influenzae in patients with chronic non-specific lung disease. Clin Allergy 1982, 12:547-559.

49. Wang XR, Zhang $H X$, Sun BX, Dai HL, Hang JQ, Eisen EA, Wegman DH, Olenchock SA, Christiani DC: A 20-year follow-up study on chronic respiratory effects of exposure to cotton dust. Eur Respir J 2005, 26:881-886

50. Michel O, Kips J, Duchateau J, Vertongen F, Robert L, Collet H, Pauwels R, Sergysels R: Severity of asthma is related to endotoxin in house dust. Am J Respir Crit Care Med 1996, 154:1641-1646.

51. Hackett TL, Holloway R, Holgate ST, Warner JA: Dynamics of proinflammatory and anti-inflammatory cytokine release during acute inflammation in chronic obstructive pulmonary disease: an ex vivo study. Respir Res 2008, 9:47.

52. Patel IS, Seemungal TA, Wilks M, Lloyd-Owen SJ, Donaldson GC, Wedzicha JA: Relationship between bacterial colonisation and the frequency, character, and severity of COPD exacerbations. Thorax 2002, 57:759-764

53. Wilkinson TM, Hurst JR, Perera WR, Wilks M, Donaldson GC, Wedzicha JA: Effect of interactions between lower airway bacterial and rhinoviral infection in exacerbations of COPD. Chest 2006, 129:317-324.

54. Toward TJ, Broadley KJ: Airway reactivity, inflammatory cell influx and nitric oxide in guinea-pig airways after lipopolysaccharide inhalation. BrJ Pharmacol 2000, 131:271-281.

55. Karimi K, Sarir H, Mortaz E, Smit JJ, Hosseini H, De Kimpe SJ, Nijkamp FP, Folkerts G: Toll-like receptor-4 mediates cigarette smoke-induced cytokine production by human macrophages. Respir Res 2006, 7:66

56. Halayko AJ, Tran T, Gosens R: Phenotype and functional plasticity of airway smooth muscle: role of caveolae and caveolins. Proc Am Thorac Soc 2008, 5:80-88

57. Halayko AJ, Salari H, MA X, Stephens NL: Markers of airway smooth muscle cell phenotype. Am J Physiol 1996, 270:L1040-L1051.

58. Halayko AJ, Solway J: Molecular mechanisms of phenotypic plasticity in smooth muscle cells. J Appl Physio/ 2001, 90:358-368

59. Gosens R, Nelemans SA, Grootte Bromhaar MM, McKay S, Zaagsma J, Meurs H: Muscarinic M3-receptors mediate cholinergic synergism of mitogenesis in airway smooth muscle. Am J Respir Cell Mol Biol 2003, 28:257-262.

60. Ammit AJ, Panettieri RA Jr: Invited review: the circle of life: cell cycle regulation in airway smooth muscle. J Appl Physio/ 2001, 91:1431-1437.

61. Ramakrishnan M, Musa NL, Li J, Liu PT, Pestell RG, Hershenson MB: Catalytic activation of extracellular signal-regulated kinases induces cyclin D1 expression in primary tracheal myocytes. Am J Respir Cell Mol Biol 1998, 18:736-740.

62. Orsini MJ, Krymskaya VP, Eszterhas AJ, Benovic JL, Panettieri RA Jr, Penn RB: MAPK superfamily activation in human airway smooth muscle: mitogenesis requires prolonged p42/p44 activation. Am J Physiol 1999, 277:L479-L488.
63. Lee JH, Johnson PR, Roth M, Hunt NH, Black JL: ERK activation and mitogenesis in human airway smooth muscle cells. Am J Physiol Lung Cell Mol Physiol 2001, 280:L1019-L1029.

64. Karpova AY, Abe MK, Li J, Liu PT, Rhee JM, Kuo WL, Hershenson MB: MEK1 is required for PDGF-induced ERK activation and DNA synthesis in tracheal myocytes. Am J Physiol 1997, 272:L558-L565.

65. Fernandes DJ, Ravenhall CE, Harris T, Tran T, Vlahos R, Stewart AG: Contribution of the $\mathrm{p} 38$ MAPK signalling pathway to proliferation in human cultured airway smooth muscle cells is mitogen-specific. $\mathrm{Br}$ J Pharmacol 2004, 142:1182-1190.

66. Zhai W, Eynott PR, Oltmanns U, Leung SY, Chung KF: Mitogen-activated protein kinase signalling pathways in IL-1 beta-dependent rat airway smooth muscle proliferation. Br J Pharmacol 2004, 143:1042-1049.

67. Chen $G$, Khalil N: TGF-beta1 increases proliferation of airway smooth muscle cells by phosphorylation of map kinases. Respir Res 2006, 7:2.

68. Vlahos R, Lee KS, Guida E, Fernandes DJ, Wilson JW, Stewart AG: Differential inhibition of thrombin- and EGF-stimulated human cultured airway smooth muscle proliferation by glucocorticoids. Pulm Pharmacol Ther 2003, 16:171-180.

69. Cheng SE, Luo SF, Jou MJ, Lin CC, Kou YR, Lee IT, Hsieh HL, Yang CM: Cigarette smoke extract induces cytosolic phospholipase A2 expression via NADPH oxidase, MAPKs, AP-1, and NF-kappaB in human tracheal smooth muscle cells. Free Radic Biol Med 2009, 46:948-960

70. Sturrock A, Huecksteadt TP, Norman K, Sanders K, Murphy TM, Chitano P, Wilson K, Hoidal JR, Kennedy TP: Nox4 mediates TGF-beta1-induced retinoblastoma protein phosphorylation, proliferation, and hypertrophy in human airway smooth muscle cells. Am J Physiol Lung Cell Mol Physiol 2007, 292:L1543-L1555.

71. Lin WN, Luo SF, Lee CW, Wang CC, Wang JS, Yang CM: Involvement of MAPKs and NF-kappaB in LPS-induced VCAM-1 expression in human tracheal smooth muscle cells. Cell Signal 2007, 19:1258-1267.

doi: 10.1186/1465-9921-11-48

Cite this article as: Pera et al., Cigarette smoke and lipopolysaccharide induce a proliferative airway smooth muscle phenotype Respiratory Research 2010, 11:48

\section{Submit your next manuscript to BioMed Central and take full advantage of:}

- Convenient online submission

- Thorough peer review

- No space constraints or color figure charges

- Immediate publication on acceptance

- Inclusion in PubMed, CAS, Scopus and Google Scholar

- Research which is freely available for redistribution
C) Biomed Central 